\title{
Fluorescein study of a family with angioid streaks and pseudoxanthoma elasticum
}

\author{
DAVID S. HULL AND THOMAS M. AABERG \\ From the Department of Ophthalmology, Retina Section, Medical College of Wisconsin (formerly \\ Marquette School of Medicine), Milwaukee, Wisconsin
}

Angioid streaks appear ophthalmoscopically as a network of red or dark brown streaks emanating from a more or less complete peripapillary ring of the same colour. Angioid streaks may occur alone or in association with various systemic diseases including pseudoxanthoma elasticum. The combination of angioid streaks and pseudoxanthoma elasticum comprises the Grönblad-Strandberg syndrome. Of patients with typical pseudoxanthoma elasticum 85 per cent. have been noted to have angioid streaks (Connor, Juergens, Perry, Hollenhorst, and Edwards, i96r).

Fluorescein angiography and the interpretation of the finding in patients with known angioid streaks have been reported many times (Smith, Gass, and Justice, 1964; Norton, Gass, Smith Curtin, David, and Justice, I965; Tanenbaum and de Marjerie, I966; Rosen, I968; Wessing and von Noorden, I969; Patnaik and Malik, I97 I). The present study was undertaken to document the progressive changes caused by angioid streaks in two generations of a family with pseudoxanthoma elasticum in which the afflicted members ranged from the second to seventh decades. Fluorescein angiography was evaluated as a means of detecting early angioid streaks, or some other early ocular manifestation of pseudoxanthoma elasticum observable only by this method and not previously described. To our knowledge, this is the first fluorescein study of two generations of a family known to have angioid streaks and pseudoxanthoma elasticum.

\section{Method}

Members of two consecutive generations of a family with known pseudoxanthoma elasticum were studied by indirect ophthalmoscopy, fundus biomicroscopy, colour fundus photography, and fluorescein angiography. Photographs were taken by stereophotography to detect minimal angioid streaks.

\section{Results}

The parents of the second generation are now deceased (Fig. I, overleaf), but it is known that neither parent had any gross visual disturbance, and that it was not a consanguineous marriage.

The second generation of this family is now in late middle-age, ranging from $5^{2}$ to 67 Address for reprints: T. M. Aaberg, M.D., Department of Ophthalmology, Medical College of Wisconsin, 8700 West Wisconsin
Avenue, Milwaukee, Wisconsin 53226, U.S.A. 


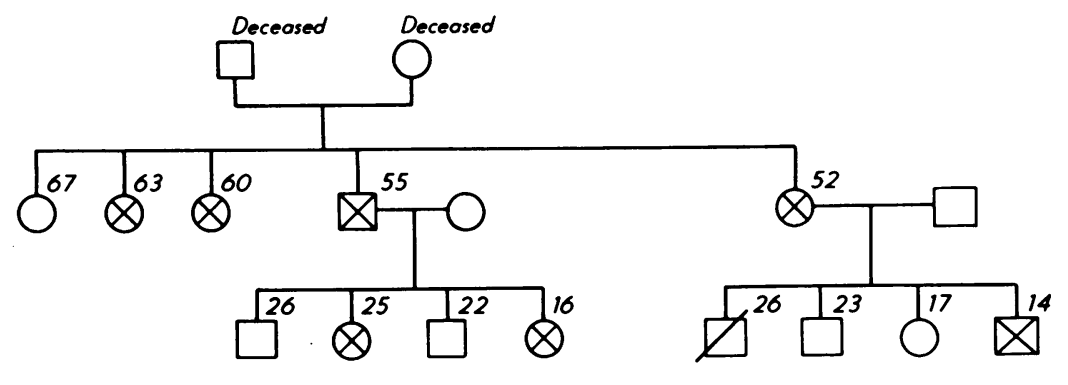

$X=$ Alfected

$I=$ Not exomined

FIG. I Family tree

years (Table I). Of the five members of this generation studied, four have angioid streaks (Fig. 2) and varying degrees of pigment epithelial degeneration of the posterior fundus (Fig. 3), accompanied by severe visual impairment in three of them. As is characteristic

Table I Particulars of five members of the second generation

\begin{tabular}{|c|c|c|c|c|}
\hline $\begin{array}{l}\text { Patient } \\
\text { no. }\end{array}$ & Sex & $\begin{array}{l}\text { Age } \\
(y r s)\end{array}$ & Examination & Fluorescein angiography \\
\hline I & $\mathbf{F}$ & 67 & $\begin{array}{l}\mathrm{R}: 6 / 6 ; \mathrm{L}: 6 / 6 \\
\text { Few drusen, no angioid streaks, no skin lesions }\end{array}$ & Not done \\
\hline 2 & $\mathbf{F}$ & 63 & $\begin{array}{l}\text { R: C.F. I m.; L: } 3 / 60 \\
\text { Angioid streaks and marked pigment epithelial } \\
\text { atrophy of posterior fundus both eyes } \\
\text { Skin clinically compatible with pseudoxanthoma } \\
\text { elasticum (PXE) }\end{array}$ & $\begin{array}{l}\text { Marked choroidal } \\
\text { atrophy and angioid } \\
\text { streaks both eyes }\end{array}$ \\
\hline 3 & $\mathbf{F}$ & 60 & $\begin{array}{l}\mathrm{R}: 6 / 24 ; \mathrm{L}: 6 / 24 \\
\mathrm{R}: \text { foveal and parafoveal pigment clumping, } \\
\text { probable angioid streaks. L: pigment in macula, } \\
\text { angioid streak } \\
\text { Skin clinically compatible with PXE }\end{array}$ & $\begin{array}{l}\mathrm{R} \text { : probable angioid } \\
\text { streak } \\
\mathrm{L}: \text { angioid streaks }\end{array}$ \\
\hline 4 & $\mathbf{M}$ & 55 & $\begin{array}{l}\mathrm{R}: 3 / 60 ; \mathrm{L}: 3 / 6 \mathrm{o} \\
\text { Angioid streaks and marked pigment epithelial } \\
\text { atrophy of posterior fundus } \\
\text { Skin - PXE-biopsy proven }\end{array}$ & Not done \\
\hline 5 & $\mathbf{F}$ & 52 & $\begin{array}{l}\mathrm{R}: 6 / 6 ; \mathrm{L}: 6 / 9 \\
\text { Angioid streaks both eyes } \\
\text { Peau d'orange change mid-periphery } \\
\text { Coarse furrows in skin of neck }\end{array}$ & Angioid streaks both eyes \\
\hline
\end{tabular}


(a)

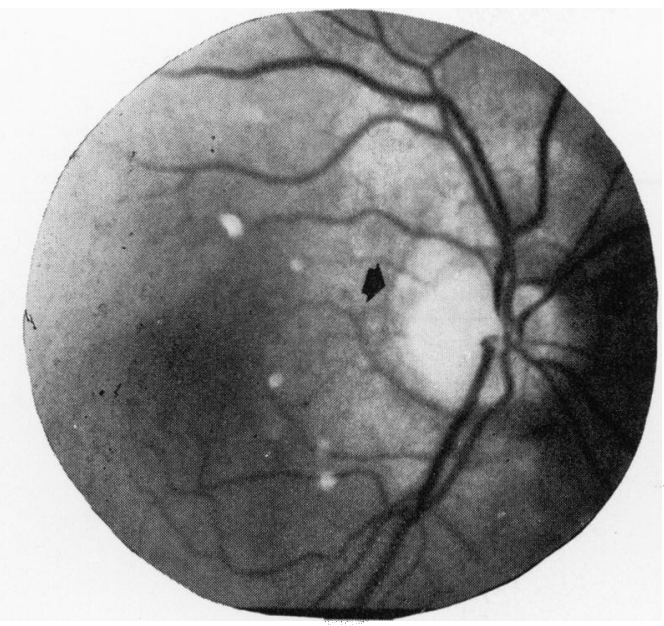

(c)

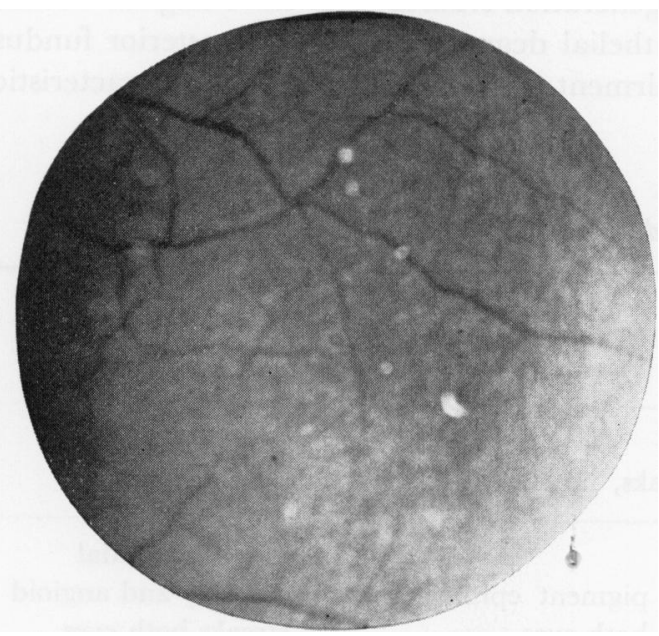

(a)

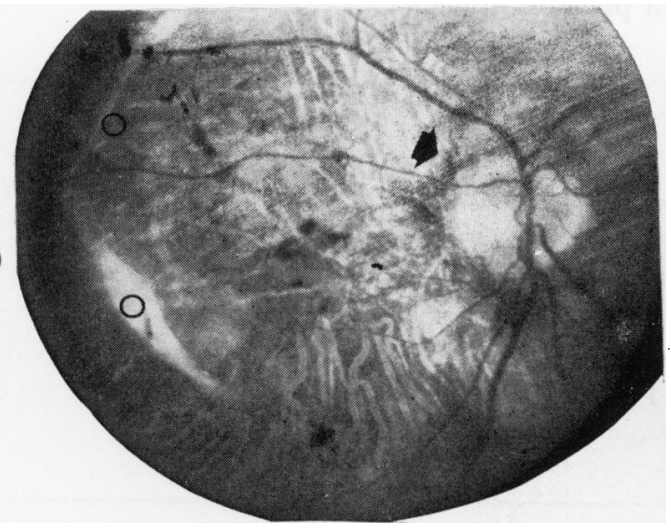

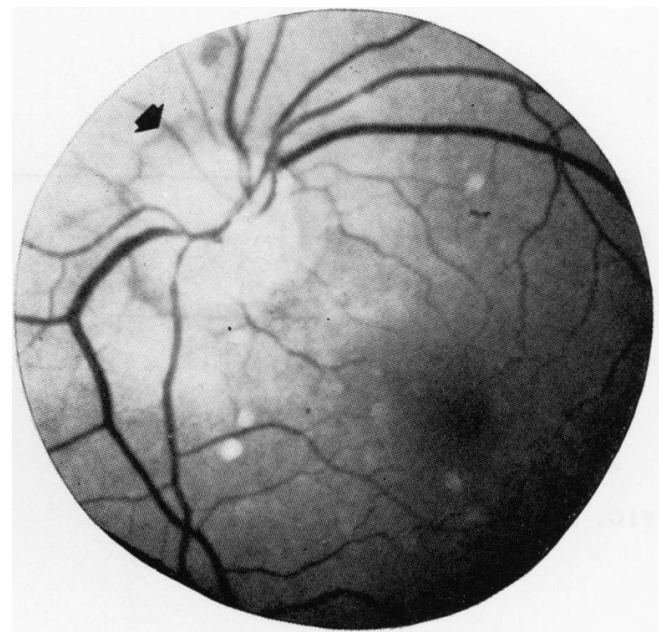

FIG. $2 a$ Patient 5. Peripapillary angioid streaks (arrows). White spots are photographic artefacts FIG. $2 b$ Patient 5. Peripapillary angioid streak (arrow). Note haemorrhage superior and nasal to disc FIG. $2 c$ Patient 5. Peau d'orange appearance, mid-periphery

FI G. $3^{a}$ Patient 2. Marked pigment epithelial atrophy and pigment clumping of posterior fundus. Angioid streak (arrow). Areas of organized subretinal tissue (o)

FIG. $3^{b}$ Patient 2. Fluorescein angiogram confirms marked choroidal atrophy (white arrow). Several choroidal vessels were shown to fill in retrograde fashion. Note in comparison Fig. 3a, where streak (black arrow) is not delineated by fluorescence which is very diffuse

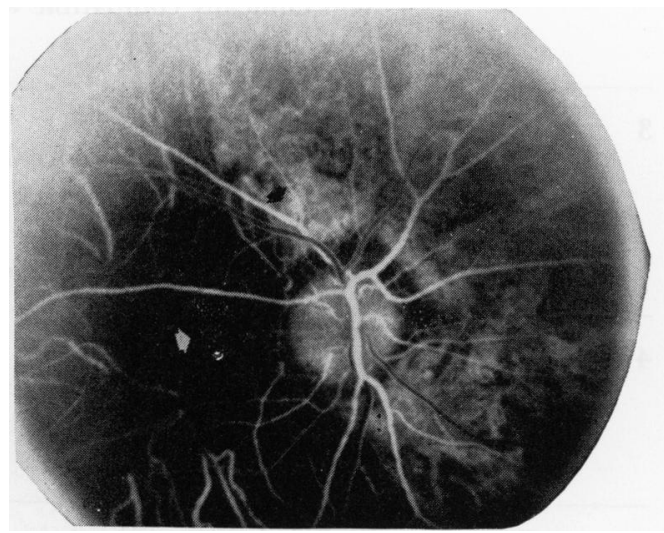


of the visual impairment associated with angioid streaks, all became symptomatic in their late forties or early fifties. Three of the affected members have the characteristic skin changes of pseudoxanthoma elasticum, one proven by biopsy.

Table II Particulars of seven members of the third generation

\begin{tabular}{|c|c|c|c|}
\hline $\begin{array}{l}\text { Patient } \\
\text { no. }\end{array}$ & Sex & $\begin{array}{l}\text { Age } \\
(y r s)\end{array}$ & Examination \\
\hline 6 & $\mathbf{M}$ & 26 & $\begin{array}{l}\mathrm{R}: 6 / 6 ; \mathrm{L}: 6 / 6 \\
\text { No angioid streaks } \\
\text { Skin - normal }\end{array}$ \\
\hline 7 & $\mathrm{~F}$ & 25 & $\begin{array}{l}\mathrm{R}: 6 / 6 ; \mathrm{L}: 6 / 6 \\
\mathrm{R}: \text { Possible small peripapillary angi- } \\
\quad \text { oid streak } 3 \text { to } 4 \text { o'clock. L: } \\
\text { Apparent peripapillary angioid } \\
\text { streak } 3 \text { to } 4 \text { o'clock }\end{array}$ \\
\hline & & & Skin - normal \\
\hline 8 & $\mathrm{M}$ & 22 & $\begin{array}{l}\mathrm{R}: 6 / 6 ; \mathrm{L}: 3 / 60 \text { (amblyopia) } \\
\text { Normal eye examination } \\
\text { Skin - normal }\end{array}$ \\
\hline 9 & $\mathrm{~F}$ & I 6 & $\begin{array}{l}\mathrm{R}: 6 / 6 ; \mathrm{L}: 6 / 6 \\
\mathrm{R} \text { : normal. L: slight peripapillary } \\
\quad \text { pigment epithelial atrophy. Early } \\
\text { angioid streak } 2 \text { to } 4 \text { o'clock } \\
\text { Skin - normal }\end{array}$ \\
\hline IO & $\mathrm{M}$ & 23 & $\begin{array}{l}\mathrm{R}: 6 / 6 ; \mathrm{L}: 6 / 6 \\
\text { Eye examination normal } \\
\text { Skin - normal }\end{array}$ \\
\hline I I & $\mathrm{M}$ & 17 & $\begin{array}{l}\mathrm{R}: 6 / 6 ; \mathrm{L}: 6 / 6 \\
\text { Myopia corrected }\end{array}$ \\
\hline 12 & $\mathrm{M}$ & I 4 & $\begin{array}{l}\mathrm{R}: 6 / 6 ; \mathrm{L}: 6 / 6 \\
\text { Atrophic choroidal crescent temporal } \\
\quad \text { to left disc } \\
\text { Skin - normal }\end{array}$ \\
\hline
\end{tabular}

Fluorescein angiography

Normal

$\mathrm{R}$ : Not diagnostic

$\mathrm{L}$ : Increased transmission in area of suspected angioid streak

Late pictures show no increased transmission of sclera through streak

Normal

L: Increased tıansmission in area of early angioid streak

Prominent choroidal pattern

Normal

Increased early transmission of dye in 3 to 5 o'clock peripapillary position

Late pictures continue to show increased transmission in this area

The third generation has an age range of 14 to 26 years (Table II). Seven members of this generation were studied, three of whom show evidence compatible with early angioid streaks in the peripapillary region. In two patients, the streak did not show increased transmission of fluorescence, but the area immediately adjacent to the streak did (Figs 4 and 5). Patient 12 is atypical of the three involved members of the third generation in 
$4 a$

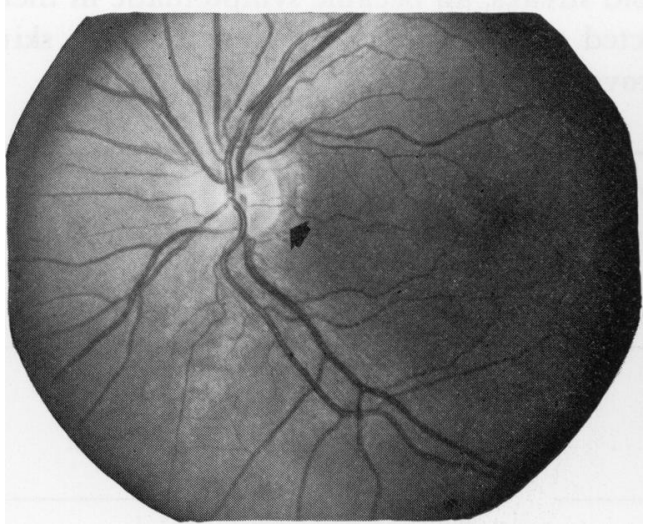

$4 b$

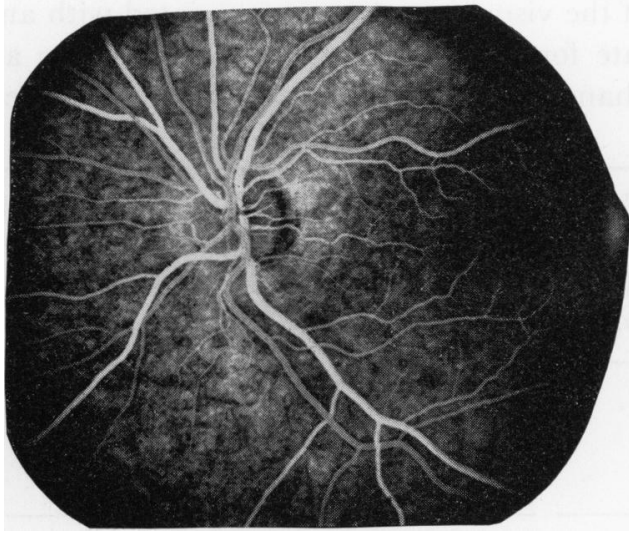

FI G. 4a Patient 7. Angioid streak (arrow)

FIG. $4^{b}$ Patient 7. Fluorescein angiogram. Angioid streak remains black; adjacent area shows increased transmission of choroidal fluorescence
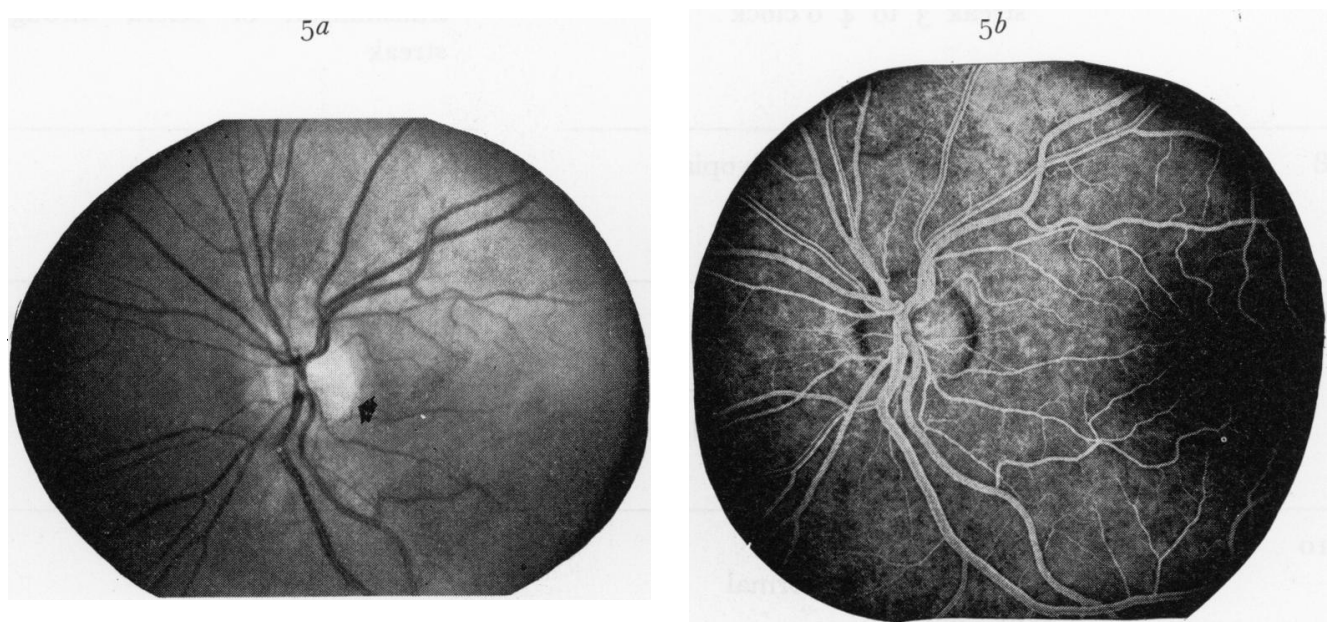

FIG. 5a Patient 9. Angioid streak (arrow)

FIG. $5^{b}$ Patient 9. Fluorescein angiography shows no hyperfluorescence of early angioid streak. Streak remained dark in the late pictures

that he alone shows early transmission of fluorescence through a peripapillary pigment epithelial defect (Fig. 6). This defect has the characteristics of a choroidal crescent which may be developmental or disease related. The developmental choroidal crescents are usually bilateral and associated with myopia. In this patient the condition is unilateral, and he is not myopic; it cannot yet be decided whether this is an early angioid streak or some other related pigment epithelial atrophy.

\section{Discussion}

Classically, the skin changes of pseudoxanthoma elasticum are characteristic. In the early stages the patient may show small chamois-coloured papules along body folds at the side of the neck and flexural regions of the extremities, axillae, and creases of the groin. Later 

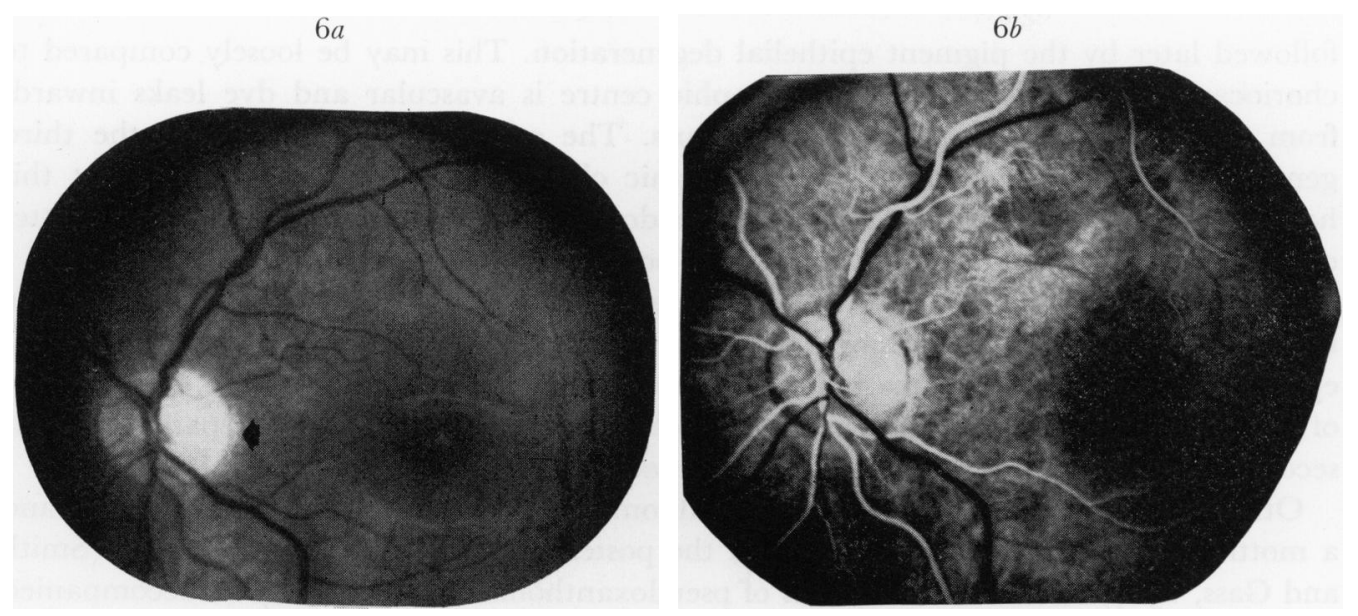

FIG. 6 a Patient 12. Peripapillary atrophic choroidal crescent (arrow)

FIG. $6 b$ Patient 12. Fluorescein angiogram shows increased transmission in region of atrophic choroidal crescent

the skin becomes thickened with the formation of grooves and ridges giving rise to an appearance that has been compared to that of a plucked chicken. The skin may also become relaxed and distended. Histologically, the skin changes are diagnostic in that deep in the dermis there is an apparent increase in the number of elastic fibres which are fragmented, disorganized, and calcified (Tunbridge Tattersall, Hall, Astbury, and Reed, I952; Huang, Steele, Kumar, and Parker, 1967). It has been debated whether the abnormal fibres are altered collagen or represent elastic tissue degeneration. Recent evidence with high-resolution electron microscopy has revealed that the aetiology lies with abnormal elastic tissue genesis (Huang and others, r967).

Pseudoxanthoma elasticum is not only an ocular and dermatological disease, but also has widespread systemic manifestations. It has been associated with premature calcification of the arteries of the extremities and heart (Connor and others, I96r; Scheie and Hogan, I957; Goodman, Smith, Paton, Bergman, Siegal, Ottesen, Shelley, Pusch, and McKusick I963), and with gastrointestinal haemorrhage (Goodman and others, I963; Woo, and Chandler, 1958), so that it is truly a disease of widespread elastic tissue degeneration.

Angioid streaks may be the first manifestation of pseudoxanthoma elasticum. Krill and Archer (I97I), in a recent classification of the choroidal atrophies, suggested that in the earliest stages some angioid streaks were probably manifested first as degeneration of the pigment epithelium of the retina. This is characterized by pigment stippling and mottling, and occasionally by formation of pigment clumps. These areas are hyperfluorescent on fluorescein angiography. Degeneration of the choriocapillaris follows the pigment epithelial degeneration with the subsequent development of breaks in Bruch's membrane characteristic of angioid streaks. Two of the patients in the third generation show no fluorescence of the streak itself, but rather increased transmission around the suspected streaks. The meaning of this is not entirely clear, but it is not compatible with the possibility that in pseudoxanthoma elasticum the primary defect lies in the pigment epithelium. Certainly it tends to confirm the histological findings of earlier investigators that the primary defect is in Bruch's membrane (Hagedoorn, 1939; Verhoeff, I948; Klien, 1947; Paton, 1972).

We are also of the opinion that the breaks in Bruch's membrane are primary, and are 
followed later by the pigment epithelial degeneration. This may be loosely compared to choriocapillaris atrophy where the atrophic centre is avascular and dye leaks inwards from the surrounding viable choriocapillaris. The other affected patient in the third generation demonstrated a unilateral atrophic choroidal crescent. Whether or not this has any relationship to angioid streaks or pseudoxanthoma elasticum is at present a matter of conjecture. Certainly this finding has not been previously noted.

Angioid streaks may remain stationary, although they are frequently associated in middle life with subretinal haemorrhage, subretinal pigmentary deposits, patches of pigment epithelial rarefaction, and occasionally the proliferative changes of disciform degeneration of the macula (Connor and others, I96r; Scheie and Hogan, I957). The patients of our second generation confirm this previously noted finding.

Other ocular manifestations of pseudoxanthoma elasticum include extensive drusen, and a mottled or peau d'orange appearance of the posterior and midperipheral fundus (Smith and Gass, I964). The mottled fundus of pseudoxanthoma elasticum may be accompanied by angioid streaks or may be the only ocular sign of the disease (Shimizu, I96I; Gills and Paton, 1965). It has even been suggested that the peau d'orange fundus is the necessary predecessor of all angioid streaks in pseudoxanthoma elasticum (Shimizu, I96r).

It is of considerable interest that only Patient 5 , aged 52, showed the peaud'orange change. None of the patients in the third generation showed this change, even those in whom early angioid streaks are suspected.

A prominent choroidal pattern has been noted in a previous study in some patients and has been associated with the heterozygous carrier state (Berlyne, Bulmer, and Platt, r96 I).

Patient Io showed a prominent choroidal pattern on fluorescein angiography. We are uncertain as to the significance of this and feel that, since the primary defect is in Bruch's membrane and not in the pigment epithelium, the increased visibility of choroidal circulation has no diagnostic significance.

The inheritance pattern of pseudoxanthoma elasticum is most commonly a simple recessive trait (Connor and others, I961 ; Goodman and others, 1963; Berlyne and others, r96I). Pseudoxanthoma elasticum in two successive generations with presumed dominant inheritance has previously been noted as a rare occurrence (Osbourn and Olivo, I95 I; Berlyne and others, 196I; François, I96I ; Wise, I966). In some of the families noted in earlier studies, there was a consanguineous marriage. Berlyne and others ( $196 \mathrm{I}$ ) suggested that transmission might be partially sex-linked; however, recent cytological and genetic evidence suggests that this is impossible in man (McKusick, I962).

The mode of transmission in this family is most likely dominant. In the second generation, four of the five members examined were affected with the disease. In the third generation, two and possibly three of the seven members examined were affected. Both of these generations showed frequencies of occurrence greater than the one-in-four expected if the gene were recessive.

\section{Conclusions}

Several conclusions may be drawn:

(r) The third generation of this family shows signs of angioid streaks in the second and early third decades of life;

(2) The primary defect as confirmed by fluorescein angiography lies in Bruch's membrane, not in the pigment epithelium; 
(3) Peau d'orange fundus is not a necessary predecessor to angioid streaks;

(4) The genetic pattern in this family is probably dominant;

(5) Fluorescein angiography does not per se improve the ability to diagnose early angioid streaks or other ocular findings of pseudoxanthoma elasticum. All findings were noted on careful fundus examination. We conclude that fluorescein angiography in asymptomatic members of families with pseudoxanthoma elasticum and a normal fundus examination is probably not warranted.

We wish to thank John B. Hitz, M.D., for referring these patients to us for study, and Mr. Ronald Kacizak for his help with the photography and technical advice in the reproduction of the photographs.

\section{References}

Berlyne, G. M., BUlmer, M. G., and Platt, R. (I96I) Quart. J. Med., 30, 20 I

CONNOR, P. J., JUERgens, J. L., PERRY, H. O., hOllenhorst, R. W., and edWARDs, J. E. (I96i) Amer.

7. Med., 30, 537

FRANÇoIs, J. (I96I) "Heredity in Ophthalmology", p. 675. Mosby, St. Louis

GILls, J. P., JR., and PATON, D. (I965) Arch. Ophthal. (Chicago), 73, 792

Goodman, R. M., SMith, E. W., PATON, D., Bergman, R. A., SIEgel, G. L., OTTESEN, O. E., SHELley, W. M., PUSCH, A. L., and McKusick, v. A. (1963) Medicine (Baltimore), 42, 297

hagedoorn, A. (1939) Arch. Ophthal. (Chicago), 21, 746

huang, s. N., steele, H. D., Kumar, G., and Parker, J. o. (1967) Arch. Path., 83, io8

KLIEN, B. A. (I947) Amer. 7. Ophthal., 30, 955

KRILL, A. E., and ARGHER, D. (I97I) Ibid., 72, 562

McKusick, v. A. (Ig62) Quart. Rev. Biol., 37, 69

NORTON, E. W. D., GAss, J. D., SMith, J. L., CURTIN, v. T., DAVID, N. J., and Justice, J. (1965) Trans.

Amer. Acad. Ophthal. Otolaryng., 69, 631

osbourn, R. A., and olivo, м. A. (I95I) Arch. Derm., 63, 66 I

PATNAIK, B., and MALIK, s. R. K. (197I) Brit. J. Ophthal., 55, 833

PATON, D. (1972) "The Relation of Angioid Streaks to Systemic Disease", p. 31. Thomas, Springfield,

Ill.

Rosen, E. (ig68) Amer. F. Ophthal., 66, 236

SGheie, H. G., and hogan, T. F., JR. (1957) A.M.A. Arch. Ophthal. 57, 855

shimizu, к. (Ig6r) Jap. 7. Ophthal., 5, I

SMith, J. L., GASS, J. D. M., and JUSTICE, J., JR. (1964) Brit. J. Ophthal., 48, 5 I 7

tanenbaum, H. L., and Margerie, J. DE (ig66) Canad. F. Ophthal., I, 22 I

TUNBridge, R. E., tATtersall, R. N., Hall, D. A., AStbury, W. T., and Reed, R. (i952) Clin. Sci., II,

3 I 5

VERHOEFF, F. H. (I948) Brit. J. Ophthal., 32, 53 I

WEssing, A., and Noorden, G. K. von (I969) "Fluorescein Angiography of the Retina", p. I 26.

Mosby, St. Louis

WISE, D. (I966) "Hereditary disorders of connective tissue", in "Vererbung von Hautkrankheiten"

ed. H. H. GotTRon and U. W. SChNYDER, pp. 467-532. Springer, Berlin

woo, J. C.. JR., and Chandler, F. w. (1958) Ann. intern. Med., 49, 2 I 5 